\title{
A-242 Aluminium Alloy Foams Manufacture from the Recycling of Beverage Cans
}

\author{
Nallely Montserrat Trejo Rivera * ${ }^{(0)}$, Jesús Torres Torres and Alfredo Flores Valdés \\ Centro de Investigación y de Estudios Avanzados del Instituto Politécnico Nacional, Unidad Saltillo, \\ Avenida Industria Metalúrgica 1062, Parque Industrial Saltillo-Ramos Arizpe, 25900 Ramos Arizpe, Coahuila, \\ Mexico; jesus.torres@cinvestav.edu.mx (J.T.T.); alfredo.flores@cinvestav.edu.mx (A.F.V.) \\ * Correspondence: nallely.trejo@cinvestav.edu.mx; Tel.: +52-844-438-9600
}

Received: 5 December 2018; Accepted: 11 January 2019; Published: 16 January 2019

\begin{abstract}
This paper presents and discusses a methodology implemented to study the process of the preparation of aluminium alloy foams using the alloy A-242, beginning from the recycling of secondary aluminium obtained from beverage cans. The foams are prepared by a melting process by adding $0.50 \mathrm{wt} . \%$ calcium to the A-242 aluminium alloy with the aim to change its viscosity in the molten state. To obtain the foam, titanium hydride is added in different concentrations $(0.50 \mathrm{wt} . \%$, $0.75 \mathrm{wt} . \%$, and $1.00 \mathrm{wt} . \%$ ) and at different temperatures $(923,948 \mathrm{~K}$, and $973 \mathrm{~K}$ ) while the foaming time is kept constant at $30 \mathrm{~s}$. For a set of experimental parameter values, aluminium alloy foams with the average relative density of 0.12 were obtained and had an $88.22 \%$ average porosity. In this way, it is possible to state that the preparation of aluminium alloy foams A-242 processed from the recycling of cans is possible, with characteristics and properties similar to those obtained using commercial-purity metals.
\end{abstract}

Keywords: aluminium alloy foam; recycling; beverage cans; direct foaming method; A-242 alloy

\section{Introduction}

Aluminium and its alloys are highly recyclable metals that are easily used for the preparation of several specific alloys, and there are claims that the practice of recycling aluminium allows to reduce pollution and contributes to saving electrical energy as compared to the primary aluminium obtaining process. The recycling process is suitable as aluminium cans from discarded beverages are composed mainly of aluminium alloys, so any separation methods for other materials are not required [1].

Recycling is desirable when the environmental and economic implications of their reintegration do not exceed the limits of their primary production [2]. Aluminium is used in present times like no other metal, together with steel, so its production is continuously growing, with an average growth of $3.7 \%$ per annum [3]. Its physical properties make it an ideal candidate for a range of applications in industries such as packaging, transportation, construction, and aerospace, among others [4]. However, secondary aluminium production faces problems with quality losses (when the purity of the aluminium produced is lower than the input material, e.g., by adding alloying elements during re-melting) and dilution losses (addition of primary aluminium during melting to dilute the concentration of residual elements that cannot be refined), accumulation of impurities, and unlimited options for purification of the molten mass [5-8]. Nevertheless, several studies have addressed the fact that aluminium recycling needs no more than $5 \%$ of the energy needed for its primary production, so it presents a real opportunity to reduce environmental impacts if managed in a sustainable way $[9,10]$.

On the other hand, it is well known that for the 2XX series of alloys, copper is the main alloying element, so these types of alloys are thermally treatable. Some of the properties that they present are good ductility, high tensile strength $(275 \mathrm{MPa})$ and compressive yield strength (235 MPa). During 
solidification, the main alloying elements form intermetallic phases which precipitate in different morphologies, giving rise to various properties. Copper is slightly soluble in aluminium at room temperature $(0.2 \%)$; however, increasing the temperature $(821 \mathrm{~K})$ can dissolve up to $5.65 \%$ copper. During the solidification process of the A-242 aluminium alloy, the intermetallic compound $\mathrm{Al}_{2} \mathrm{Cu}$ is formed as a result of a eutectic reaction, improving resistance and hardness in the as-cast condition. With high copper content ( 4 to $6 \%$ ), the aluminium alloy responds strongly to heat treatments. On the other hand, nickel forms the intermetallic $\mathrm{Al}_{3} \mathrm{Ni}$ with aluminium on solidification, which improves the properties at high temperatures, also reducing the coefficient of thermal expansion. This alloy is used in the manufacture of cylinder heads for motorcycles and pistons [11]. Table 1 shows the chemical composition of the A-242 alloy [12].

Table 1. Chemical composition of A-242 aluminium alloy (wt.\%).

\begin{tabular}{ccccccccccc}
\hline $\mathbf{A l}$ & $\mathbf{S i}$ & $\mathbf{F e}$ & $\mathbf{C u}$ & $\mathbf{M n}$ & $\mathbf{M g}$ & $\mathbf{C r}$ & $\mathbf{N i}$ & $\mathbf{Z n}$ & $\mathbf{T i}$ & Others \\
\hline Balance & 0.70 & 1.00 & $3.5-4.5$ & 0.35 & $1.2-1.8$ & 0.25 & $1.7-2.3$ & 0.35 & 0.25 & 0.15 \\
\hline
\end{tabular}

The automotive industry is constantly searching for innovation in its products, giving the opportunity to develop and innovate new materials which allow a better fuel efficiency and passenger safety [13]. Aluminium foams are an attractive alternative for this purpose because their properties are ideal for this purpose as its lightness and ability to absorb impact energy.

Metal foams are light materials in which a gas dispersed in a metal matrix occupies between 50 and $90 \%$ of the total volume, obtaining low density values $\left(0.3-0.8 \mathrm{~g} / \mathrm{cm}^{3}\right)$. They are characterized by a combination of mechanical and physical properties resulting from both the porous structure and the characteristics of the metal from which they were manufactured $[14,15]$. Depending on the production method, the foam structure is more or less homogeneous and comprises different characteristic features that determine its properties and, therefore, the fields of application [16,17].

However, less common and familiar are applications and products based on metal foams. The reason is that they are still not widespread, although they have a very high potential, and a large number of applications already exist on the market. Some reviews about the applications of metallic foams are available in the literature [16-22]; however, in recent years, new application fields have emerged, and not all are considered commercially relevant.

The main applications of metal foams can be grouped into structural and functional applications, and are based on several excellent properties of the material [17]. Structural applications take advantage of the light-weight and specific mechanical properties of metal foams; functional applications are based on a special functionality, i.e., a large open area in combination with very good thermal or electrical conductivity for heat dissipation or as electrode for batteries, respectively [16].

There are a large number of manufacturing methods for metal foams. The closed porosity metal foams are commonly fabricated by direct and indirect foaming methods, such as the melting (ML) and powder metallurgical (PM) methods [16,17], respectively. These methods are already described in the literature [16,17,23-26].

Shinko Wire provided the first commercial production of metal foams in the late 1980s. In this process, calcium is first added to an aluminium melt and stirred in air to produce oxides and raise its viscosity. Subsequently, the powder of the blowing agent $\left(\mathrm{TiH}_{2}\right)$ is dispersed quickly into the melt by stirring, decomposing into gaseous hydrogen and titanium at the melt temperature. The melt starts then foaming inside the crucible or inside a mold. Finally, it is cooled down to a big block and usually sliced into plates of the desired thickness. This type of metallic foam and the corresponding process is called Alporas, which was patented in America in 1987 [16,27].

Another process to manufacture aluminium alloy foams melt was invented in the early 1990s by Alcan International Limited in Montreal (QC, Canada) [28], and Norsk Hydro (Oslo, Norway). In this process, the melt needs to be prepared with ceramic particles, such as silicon carbide or aluminium oxides, ranging from 5 to $20 \mathrm{vol} \%$ to increase the viscosity of the melt and to stabilize the liquid cell 
walls. Subsequently, air bubbles are injected and, at the same time, dispersed into the melt using rotating impellers. The bubbles rise to the top of the melt, where they are collected in a liquid foam and start solidifying after leaving the furnace, where the foam can be continuously drawn off using a conveyor belt. This method is used nowadays by Cymat (Mississauga, ON, Canada) to produce foam panels or to fill molds with foams that do not need further processing [16].

In the 1950s, Allen et al. patented a method for foaming metal [29]. This route consists of an indirect foaming of solid precursors by heating. The precursor is produced by mixing aluminium powders with the corresponding alloying elements and a blowing agent, typically 0.5 to $1.0 \mathrm{wt} \%$ of $\mathrm{TiH}_{2}$. Once the powder mixture is prepared, it is consolidated and sintered by extrusion, uniaxial compaction or rolling to yield a foamable precursor. By the heating of the precursors, the matrix starts melting, and the gas of the blowing agent nucleates. In the course of the temperature increasing, hydrogen production increases, and the gas diffuses to the nucleated pores, letting them grow into big bubbles and expanding the foam. The resident oxides in the metal powders (usually 0.5 to $1 \%$ ) provide the stability of the foam during the holding time in the liquid state [30]. After several minutes, the foam development is fulfilled, and the foamed metal structure can be conserved by temperature reduction, leading to foam solidification [16].

Applications of metal foams are strongly linked to the properties that such kinds of materials can offer and especially to those that are excellent or even unique. Some of the properties are obviously mainly related to those of the matrix metal itself, e.g., elasticity, temperature or corrosion resistance, etc., while others appear only in combination with the cellular structure, e.g., low density, large surface area or damping [16].

The mechanical properties of metal foams are of course correlated to the ones of the corresponding bulk metal, but in a specific manner. The dominating factors here are the density and the structure itself. The foam structure is obviously the characteristic feature of a foam. Mechanical properties depend mainly on the density but are also influenced by the quality of the cellular structure in the sense of cell connectivity, cell roundness and diameter distribution, fraction of the solid contained in the cell nodes, edges or the cell faces [16,26,31-36].

The main objective of this work was the preparation A-242 aluminium alloy foams, obtained by adjusting the chemical composition of secondary aluminium from the recycling of beverage cans. On the other hand, taking into account that during solidification of the aluminium alloy foam, the precipitation of various intermetallic compounds occurs (i.e., $\mathrm{Al}_{2} \mathrm{Cu}, \mathrm{Al}_{3} \mathrm{Ni}, \mathrm{Al}_{9} \mathrm{FeNi}_{2} \mathrm{Al}_{2} \mathrm{CuMg}, \mathrm{Ti}$, $\mathrm{Al}_{3} \mathrm{Ti}$ ), it was interesting to study the effects of the processing temperature and the content of titanium hydride used on the formation in the aluminium alloy foams and mechanical behavior during the compression test.

\section{Materials and Methods}

\subsection{Preparation of Aluminium Alloy Foam}

The cans are composed mainly of three different alloys, i.e., the body corresponds to the A-3004 alloy, the lid to the A-5182 alloy, and the seal to the A-5082 alloy [37]. Once melted, the composition of the obtained alloy is similar to that described in Table 2. Compacted cans were melted in a gas-fired furnace containing a silicon carbide crucible with a capacity of $60 \mathrm{~kg}$. Once the temperature of $1023 \mathrm{~K}$ was attained, a flux was added to the molten bath to remove impurities from the alloy.

Once the beverage cans were melted, the chemical composition was adjusted with additions of pure copper ( $4 \mathrm{wt} . \%$ ) and electrolytic nickel ( $2 \mathrm{wt} . \%)$ at a temperature of $1293 \mathrm{~K}$ to bring the mixture to the A-242 alloy specification. The amounts of alloying elements to be added were calculated using the following equation:

$$
X=\frac{(P \mathrm{c})(C)}{100 \%}
$$


where $X$ is the amount, in grams, of the alloying element to be added $(\mathrm{Cu}, \mathrm{Ni}) ; P_{\mathrm{c}}$ is the weight of the load as melted (g); and $C$ is the difference between the weight percentage necessary to attain the composition and the initial one. Table 3 shows the final chemical composition of the A-242 aluminium alloy obtained from the adjustment of the chemical composition after the melting step.

Table 2. Chemical compositions of the alloys contained in the aluminium cans and the final composition of the fused alloy (base alloy) in wt.\%.

\begin{tabular}{ccccccccccc}
\hline Alloy & Al & Si & Fe & $\mathbf{C u}$ & $\mathbf{M n}$ & $\mathbf{M g}$ & $\mathbf{N i}$ & $\mathbf{T i}$ & $\mathbf{C r}$ & $\mathbf{Z n}$ \\
\hline $\begin{array}{c}\text { Body } \\
\text { A-3004 }\end{array}$ & Balance & 0.30 & 0.70 & 0.25 & $1.00-1.50$ & $0.80-1.30$ & - & - & - & 0.25 \\
$\quad \begin{array}{l}\text { Lid } \\
\text {-5182 }\end{array}$ & Balance & 0.20 & 0.35 & 0.15 & $0.20-0.50$ & $4.00-5.00$ & - & 0.10 & 0.10 & 0.25 \\
$\begin{array}{c}\text { Seal } \\
\text { A-5082 } \\
\text { Base } \\
\text { alloy }\end{array}$ & Balance & 0.20 & 0.35 & 0.15 & 0.15 & $4.00-5.00$ & - & 0.10 & 0.15 & 0.25 \\
\hline
\end{tabular}

Table 3. Chemical composition of the A-242 aluminium alloy obtained after the melting and composition adjustment steps.

\begin{tabular}{ccccccccccc}
\hline Alloy & Al & $\mathbf{S i}$ & $\mathbf{F e}$ & $\mathbf{C u}$ & $\mathbf{M n}$ & $\mathbf{M g}$ & $\mathbf{N i}$ & $\mathbf{T i}$ & $\mathbf{C r}$ & $\mathbf{Z n}$ \\
\hline A-242 & Balance & 0.25 & 0.66 & 3.68 & 0.81 & 0.77 & 1.94 & - & 0.02 & 0.09 \\
\hline
\end{tabular}

The chemical compositions of the secondary aluminium and of the A-242 aluminium alloy were determined using a SpectroLAB spark emission spectrometer (Spectro Inc., Kleve, Germany).

To determine the melting temperature range of the A-242 alloy during heating, a Perkin Elmer Differential Thermal Analyzer 7 (Seiko Instruments Inc, Chiba, Japan) was used. Three tests were carried out at a heating speed of $10^{\circ} \mathrm{C} / \mathrm{min}$ under an argon atmosphere. Figure 1 shows a differential thermal analysis (DTA) pattern for the obtained A-242 aluminium alloy. This shows an endothermic event in the range from 869 to $931 \mathrm{~K}$, related to the starting temperatures of the melting of the A-242 aluminium alloy.

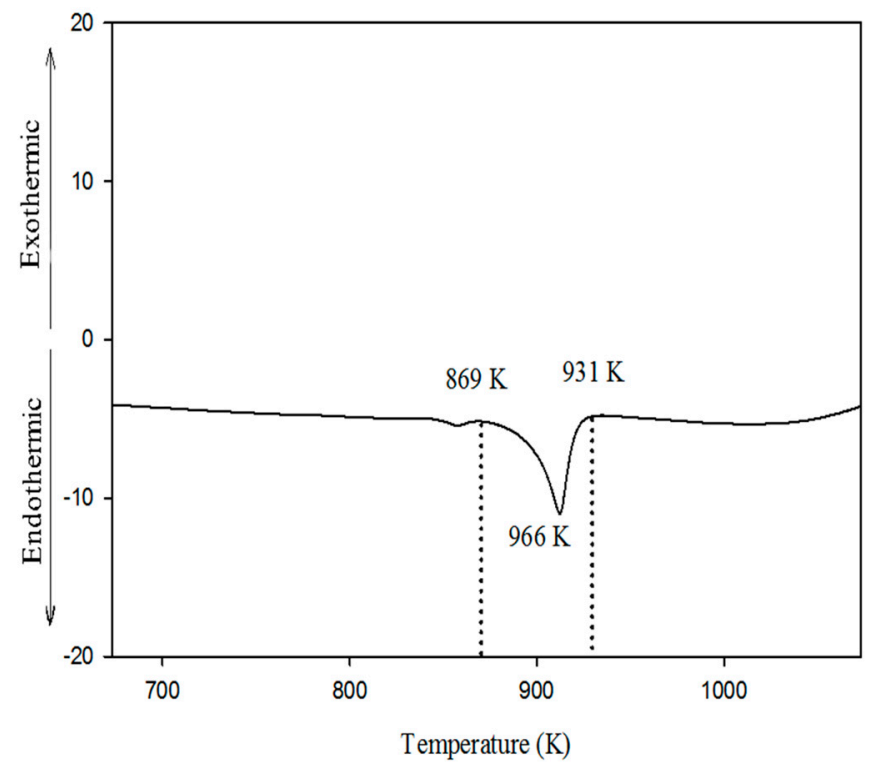

Figure 1. DTA pattern for the A-242 aluminium alloy. 
The next step was the preparation of A-242 aluminium alloy foams. At this step, the effects of the content of the foaming agent and the foaming temperature on the mechanical properties and microstructure of the aluminium alloy foams were investigated. Table 4 presents the parameters and their values studied.

Table 4. Values selected for the preparation of A-242 aluminium alloy foams (foaming time is constant for $30 \mathrm{~s})$.

\begin{tabular}{ccc}
\hline Sample & \% $\mathbf{T i H}_{\mathbf{2}}$ & Foaming Temperature (K) \\
\hline $\mathrm{A} 1$ & 0.50 & 923 \\
$\mathrm{~A} 2$ & 0.75 & 923 \\
$\mathrm{~A} 3$ & 1.00 & 923 \\
$\mathrm{~A} 4$ & 0.50 & 948 \\
$\mathrm{~A} 5$ & 0.75 & 948 \\
$\mathrm{~A} 6$ & 1.00 & 948 \\
$\mathrm{~A} 7$ & 0.50 & 973 \\
$\mathrm{~A} 8$ & 0.75 & 973 \\
$\mathrm{~A} 9$ & 1.00 & 973 \\
\hline
\end{tabular}

The A-242 aluminium alloy foams were prepared in an electrical resistance furnace equipped with a mechanical agitator using a bipartite steel mold. Once the constant temperature of $923 \mathrm{~K}$ was attained, $0.50 \mathrm{wt} . \%$ Ca was added, and the mixture was shaken for $5 \mathrm{~min}$ at a speed of $1500 \mathrm{rpm}$ in order to modify the viscosity of the aluminium alloy. It is worth mentioning that the inclined plane technique was used to determine the viscosity value attained after this addition. We found that, under the conditions imposed, the aluminium alloy developed a viscosity of $0.196 \mathrm{~Pa} \cdot \mathrm{s}$ - enough to carry out the foaming process. The foaming agent was added according to the conditions depicted in Table 4, where the $\mathrm{TiH}_{2}$ thermally decomposes, releasing hydrogen [38]. The release of this gas gives rise to the formation of bubbles inside the metal held in a semisolid state. The $\mathrm{TiH}_{2}$ was allowed to react for $30 \mathrm{~s}$ with constant agitation at $3000 \mathrm{rpm}$. After the foaming time had elapsed, the mold was removed from the furnace, allowing the prepared aluminium alloy foam to solidify to room temperature (298 K). When the aluminium alloy solidifies, the bubbles are trapped in the metal, giving rise to the formation of pores inside the alloy. The aluminium alloy foams obtained are cylindrical in shape, an average of $118.06 \mathrm{~mm}$ in height, and with a diameter of $75 \mathrm{~mm}$.

\subsection{Morphological Characterization}

The expansion of the aluminium alloy only takes place in the direction of the height. Therefore, Equation (2) [39] is used to find the linear expansion of the aluminium alloy as a function of the heights of the aluminium alloy foam and of the molten metal in the mold:

$$
\alpha_{L E}=\frac{h_{1}-h_{2}}{h_{2}} \times 100 \%,
$$

where $\alpha_{L E}$ is the linear expansion of the foam, $h_{1}$ is the height of the foam, and $h_{2}$ is the height of the molten metal in the mold.

The density of the aluminium alloy foams was determined using Equation (3), where the samples used were in the form of cubes made by cutting the aluminium alloy foam. Each sample was weighed using a digital apparatus obtaining the mass of the specimen $(m)$ expressed in grams. The dimensions of the samples were also measured in order to calculate their volume $(V)$.

$$
\rho=\frac{m}{V}
$$

The relative density $\left(\rho^{*}\right)$ of the samples was estimated using Equation (4), where $\rho$ corresponds to the density of the aluminium alloy foams obtained from Equation (3), and $\rho_{s}$ for which the density of A-242 aluminium alloys $\left(2.823 \mathrm{~g} / \mathrm{cm}^{3}\right)$ [11] was used. 


$$
\rho^{*}=\frac{\rho}{\rho_{s}}
$$

The percentage of porosity was determined using Equation (5) [39]:

$$
P=\left(1-\frac{\rho}{\rho_{s}}\right) \times 100
$$

where $P$ is the percentage of porosity of the aluminium alloy foams.

To find the pore diameter, the photomicrographs obtained from the stereographic microscope were used. Image Pro Plus software (4.1, Media Cybernetics Inc., Rockville, MD, USA) was used to trace two perpendicular lines to each other within each pore; these lines give the length between two points, so 30 measurements were made per sample to find the average diameter. Figure 2 shows the image used, illustrating the pore diameter of some of the measurements.

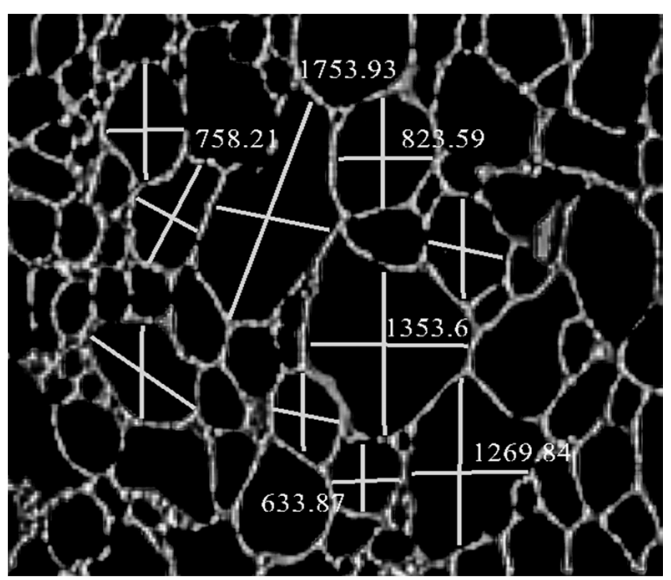

Figure 2. Measurement of the pore diameter using Image Pro Plus software.

The wall thickness measurements were performed using a scanning electron microscope (SEM) (Royal Philips Inc., Amsterdam, The Netherlands), as is shown in Figure 3 by a micrograph of the foam, indicating the measurements performed. To find the average wall thickness, 10 measurements per sample were performed.

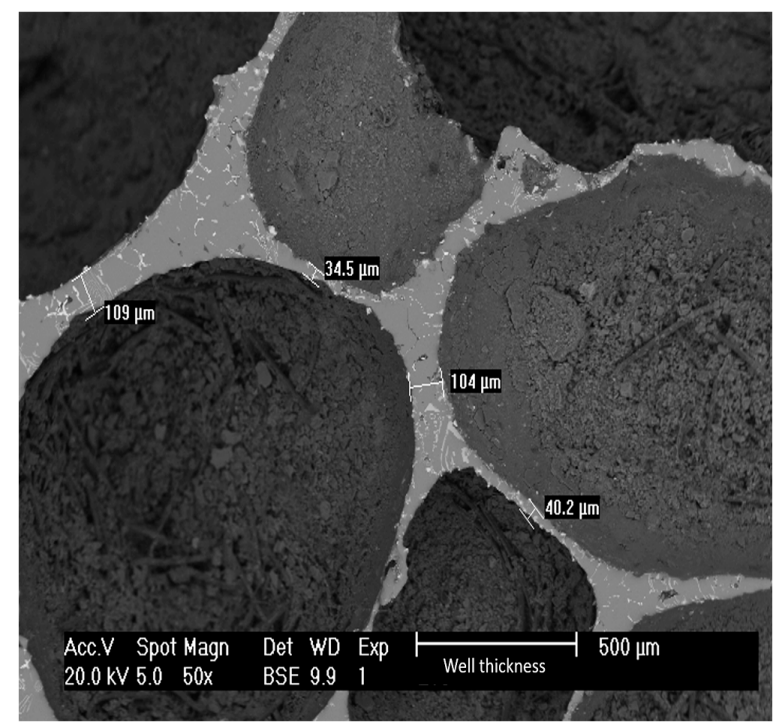

Figure 3. Scanning electron microscope (SEM) micrograph of A-242 aluminium alloy foam where the wall thickness measurements are illustrated. 
The microstructure of the A-242 aluminium alloy foams was observed using an XL30 ESEM scanning electron microscope (Royal Philips, Amsterdam, The Netherlands) equipped with a GENESIS 400 EDS (energy dispersion spectroscopy, Hi-Tech Instruments, Las Pinas, Philippines) microanalysis system to identify the intermetallic compounds present in the samples.

\subsection{Mechanical Characterization}

Finally, in order to evaluate the mechanical strength of the aluminium alloy foams under compression loads, uniaxial compression testing was carried out according to the ASTM E9 Standard procedure at room temperature. The tests were carried out using a Qtest Elite 100 model MTS electromechanical universal testing machine (MTS Inc., Berlin, Germany) with a capacity of $100 \mathrm{KN}$, equipped with TestWork software (Version 4, MTS Systems Corporation, Berlin, Germany). Cubic samples $\left(25 \times 25 \times 25 \mathrm{~mm}^{3}\right)$ were tested as shown in Figure 4 . The compression tests were performed at cross-head rates of $3 \mathrm{~mm} / \mathrm{min}$. The force and the displacement were recorded during the compression tests. The engineering stress-strain data were determined through load-displacement measurements taking into account the initial dimensions of specimens.

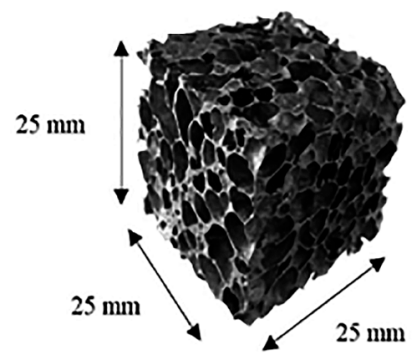

Figure 4. Image of A-242 aluminium alloy foam, showing the closed porosity attained with $0.75 \% \mathrm{TiH}_{2}$ at $948 \mathrm{~K}(\mathrm{~A} 5)$.

\section{Results and Discussion}

\subsection{Foam Morphology}

Figure 4 shows an image of A-242 aluminium alloy foam obtained using the process described in this work: a structure of closed porosity having an average relative density of 0.12 .

Figure 5 shows a photomicrograph of a A-242 aluminium alloy foam prepared with $0.75 \% \mathrm{TiH}_{2}$ at $948 \mathrm{~K}$ (A5) using a stereographic microscope, where it can be observed that the pores of the sample are not connected to each other, thus A-242 aluminium alloy foams prepared using the technique described in this work presented a structure with closed porosity.

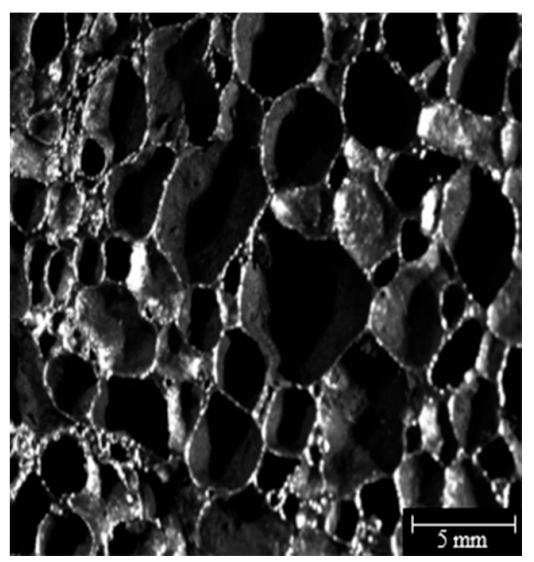

Figure 5. Stereographic photomicrography of A-242 aluminium alloy froam, obtained with $0.75 \% \mathrm{TiH}_{2}$ at $948 \mathrm{~K}$ (A5). 
The samples obtained have an average of $88.22 \%$ porosity, average pore size of $1.29 \mathrm{~mm}(0.50 \mathrm{~mm}$ standard deviation) and an average wall thickness of $114.67 \mu \mathrm{m}$ (32.61 $\mu \mathrm{m}$ standard deviation). Table 5 presents the results obtained from the linear expansion, relative density, porosity, pore diameter, and wall thickness values for A-242 aluminium alloy foams obtained in the experiments indicated. We analyzed the effect of foaming temperature and $\mathrm{TiH}_{2}$ content on the properties of A-242 aluminium alloy foams.

Table 5. Linear expansion, relative density, porosity, pore diameter and wall thickness of the indicated A-242 aluminium alloy foams ( $\sigma=$ standard deviation).

\begin{tabular}{cccccccc}
\hline Sample & $\begin{array}{c}\text { Linear } \\
\text { Expansion } \\
(\mathbf{\%})\end{array}$ & $\begin{array}{c}\text { Relative } \\
\text { Density }\end{array}$ & $\begin{array}{c}\text { Porosity } \\
\mathbf{( \% )}\end{array}$ & $\begin{array}{c}\text { Pore } \\
\text { Diameter } \\
(\boldsymbol{\mu m})\end{array}$ & $\begin{array}{c}\sigma \text { Pore } \\
\text { Diameter } \\
(\boldsymbol{\mu m})\end{array}$ & $\begin{array}{c}\text { Wall } \\
\text { Thickness } \\
(\boldsymbol{\mu m})\end{array}$ & $\begin{array}{c}\sigma \text { Wall } \\
\text { Thickness } \\
(\boldsymbol{\mu m})\end{array}$ \\
\hline A1 & 79.50 & 0.1293 & 87.07 & 633.87 & 279.74 & 148.11 & 66.84 \\
A2 & 75.01 & 0.1512 & 84.88 & 864.40 & 362.54 & 90.07 & 56.54 \\
A3 & 79.21 & 0.1451 & 85.49 & 1220.96 & 742.55 & 124.74 & 65.61 \\
A4 & 77.20 & 0.1006 & 89.94 & 1753.93 & 848.31 & 87.56 & 29.32 \\
A5 & 71.56 & 0.1327 & 86.73 & 1071.93 & 486.78 & 89.44 & 45.04 \\
A6 & 77.63 & 0.0883 & 91.17 & 2149.79 & 979.64 & 181.69 & 75.13 \\
A7 & 77.35 & 0.1410 & 85.90 & 823.51 & 268.20 & 97.48 & 38.31 \\
A8 & 80.21 & 0.1118 & 88.82 & 1388.27 & 867.70 & 92.55 & 55.82 \\
A9 & 76.98 & 0.0604 & 93.96 & 1710.11 & 699.65 & 120.43 & 54.8 \\
\hline
\end{tabular}

As can observed from the values reported in Table 5, the foaming temperature does not greatly affect the linear expansion of the aluminium alloy foams obtained or the percentage of $\mathrm{TiH}_{2}$. Duarte et al. [40] report the effects of foaming temperature for 6061 alloy foams where they found that, when the foaming temperature is close to the solidus temperature, only a slight expansion occurs. If the foaming temperature is in the solid-liquid range, a greater expansion of the foam can be observed. However, increasing the temperature above the solid-liquid region reduces the viscosity of the alloy and promotes the production of more gas $\left(\mathrm{H}_{2}\right)$ so that a greater expansion of the metal can be observed. Therefore, it is evident that the foaming process is sensitive to the foaming temperature chosen as well as the $\mathrm{TiH}_{2}$ content.

The relative density of A-242 aluminium alloy foams is highly sensitive to foaming temperature and $\mathrm{TiH}_{2}$ content. An increase in some of these parameters causes the relative density of the foam to decrease. The porosity of the foam is related to the relative density; therefore, this property is affected by both the foaming temperature and the content of $\mathrm{TiH}_{2}$.

The pore diameter and wall thickness of the pores is highly affected by the foaming temperature and the content of the foaming agent. An increase in foaming temperature produces a thinning of the pore walls effect of the coalescence and drainage phenomena of the foam (drained is a flow of molten metal from the walls into the pores edges (driven by surface tension) and through pore edges downwards driven by gravity). The same is true when a high content of $\mathrm{H}_{2}$ is released, giving rise to the phenomenon of coalescence (coalescence occurs whenever two pores merge to form a larger one) [40].

\subsection{Compression Behavior}

During the compression behavior of the foams, three characteristic zones must be evaluated: quasi-elastic, plateau, and densification [17,39].

The first area represents the quasi-elastic deformation behavior attained at smaller values of compression. A more complete analysis revealed that the deformation is partly reversible and a certain process of irreversible deformation of the foam structure occurs during the first load (depending on the density gradients, the structural composition, and microstructure of the foam). The second zone is that of constant stress or plateau, resulting in the abrupt and repeated failure of successive layers of pores 
(that in porous materials, the deformation takes place in low resistance regions, this being the one that presents the thinnest pore wall and the first contact zone during the compression test). If the foam is not perfect, then the stress in this zone shows ups and downs due to defects in the structure of the foam such as pore size distribution, low-density regions, very long pores, and walls of fractured pores. The third zone is that of densification; it begins when there are no longer enough walls of intact pores to withstand the load. The stress therefore increased quickly because the walls of the pores collided with each other, occupying the space left by the pores and causing the foam to densify, increasing its mechanical resistance $[15,41]$. Figure 6 shows the stress-strain curves of the A-242 aluminium alloy foams prepared to different processing parameters.

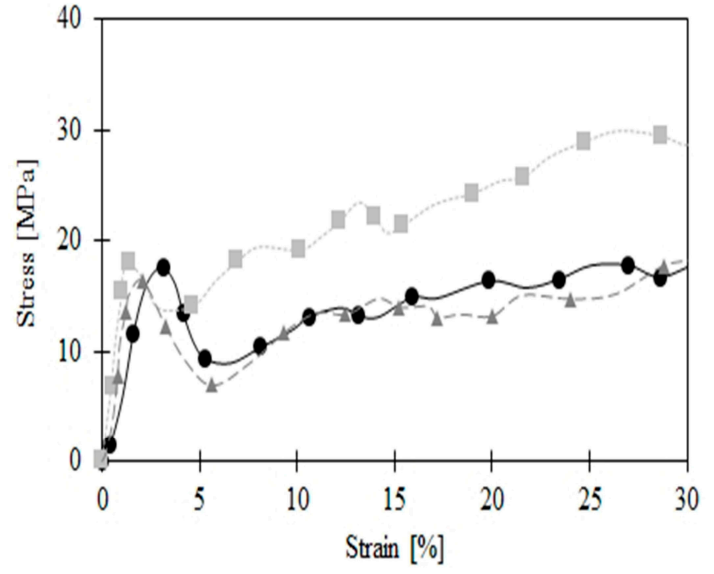

(a) $923 \mathrm{~K}$

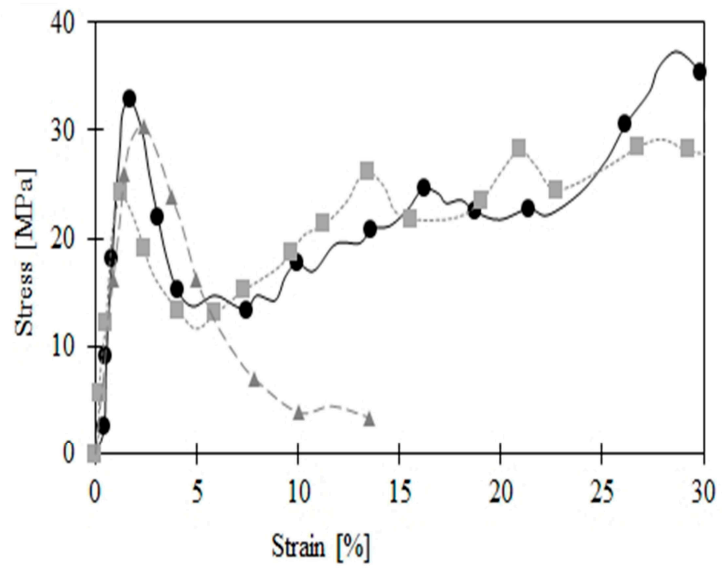

(b) $948 \mathrm{~K}$

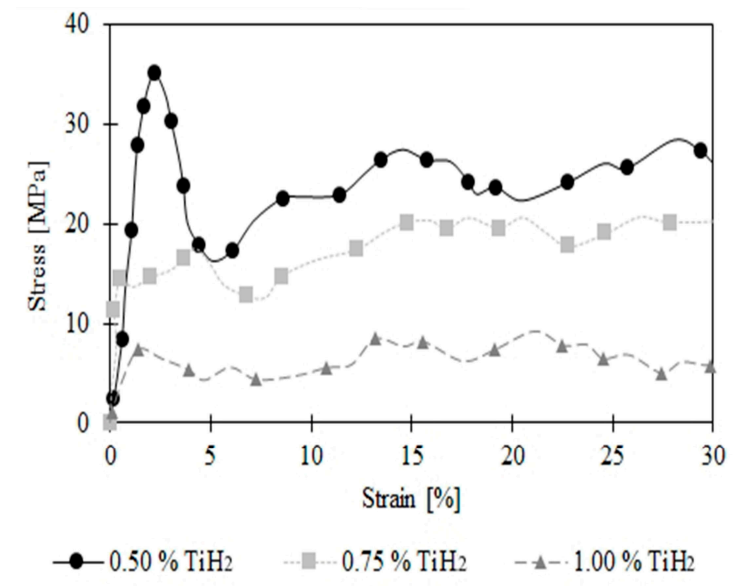

(c) $973 \mathrm{~K}$

Figure 6. Effect of the percentage of $\mathrm{TiH}_{2}$ and temperature on the mechanical behavior of A-242 aluminium alloy foams, (a) $923 \mathrm{~K}$, (b) $948 \mathrm{~K}$, (c) $973 \mathrm{~K}$.

In general, an increase in the content of the foaming agent added in the foaming process affects the internal structure of the aluminium alloy foams, i.e., by increasing pore size and decreasing resistance to deformation. The content of $\mathrm{H}_{2}$ retained in the aluminium alloy, which results from the thermal decomposition of the $\mathrm{TiH}_{2}$, causes the presence of large pores (greater than $2 \mathrm{~mm}$ ) and low relative density values (less than 0.1 ). Therefore, the presence of intermetallic compounds such as $\mathrm{Al}_{3} \mathrm{Fe}$ and $\mathrm{Al}_{2} \mathrm{CuMg}$ causes brittleness during the compression test.

The samples foamed at $923 \mathrm{~K}$ presented very similar mechanical behaviors, with the sample foamed with $0.75 \mathrm{wt} . \%$ of $\mathrm{TiH}_{2}$ being the one that presented greater densification. The samples foamed at $948 \mathrm{~K}$ presented higher resistance compared with the samples obtained at $923 \mathrm{~K}$. However, the foam with 1.00 wt. $\% \mathrm{TiH}_{2}$ did not densify; this effect is due to its structure presenting large pores and low 
density. The aluminium alloy foams manufactured at $973 \mathrm{~K}$ presented a lower mechanical resistance, mainly for contents of $0.75 \mathrm{wt} . \%$ and $1.00 \mathrm{wt} . \% \mathrm{TiH}_{2}$, the latter of which in general developed the lowest value of density. The exception to this was the aluminium alloy foam to which was added $0.50 \% \mathrm{TiH}_{2}$, since this foam is the one that presented the highest value of resistance to deformation.

The most important characteristic that affects the mechanical properties of the foams is the relative density (relation between the density the foam and that of the solid). The metal foams have relative density values of less than 0.3 [14]. An increase in the density value is related to an increase in resistance.

The literature [14] establishes that the pore size of most metal foams lies in the range from 2 to $10 \mathrm{~mm}$. Although the mechanical properties of the foams are sensitive to the wall thickness ratio (metal layer that separates one pore from another), most do not depend on the absolute pore size. The shape of the pores of the metal foams varies from equiaxial to ellipsoidal, and this has an important effect on mechanical behavior. In addition, the curvature of the walls and the chemical composition of the same affects the properties of the foam. Additives and foaming agents used to manufacture metal foams often result in unconventional alloys. An example of this is the use of $\mathrm{Ca}$ as a modifier of viscosity of the molten metal and $\mathrm{TiH}_{2}$ as a foaming agent, which introduces precipitates of $\mathrm{Al}, \mathrm{Ca}$, and $\mathrm{Ti}$ into the microstructure, weakening the walls of the pores [14]. The presence of calcium in the aluminium alloys forms intermetallic $\mathrm{Al}_{4} \mathrm{Ca}$ which presents a polyhedral morphology, being a precursor for the fracture and collapse of the foam during the compression test. In this case, the resistance of the aluminium alloy foam is expected to decrease in comparison with materials that do not present the formation of such intermetallic compounds.

Prieto et al. [42] presented a comparison of the stress-strain curves for aluminium foams obtained from the recycling of cans for beverages and pure aluminium, where the alloying elements such as $\mathrm{Fe}, \mathrm{Mn}$, and $\mathrm{Mg}$ form intermetallic compounds in the pore wall. The foam obtained from recycling presents a higher resistance than does the pure aluminium foam, an effect which is attributed to the presence of alloying elements such as $\mathrm{Ca}, \mathrm{Ti}, \mathrm{Fe}$, and $\mathrm{Mg}$ which form intermetallic compounds such as $\mathrm{Al}_{4} \mathrm{Ca}, \mathrm{Al}_{3} \mathrm{Ti}$, and $\mathrm{Al}_{6}(\mathrm{Fe}, \mathrm{Mn})$.

Figure 7 shows a comparison of the stress-strain curves of foams obtained with pure aluminium, recycled aluminium cans, and the A-242 aluminium alloy obtained from the recycling of cans. The data of pure aluminium and of recycled aluminium were obtained from the work of Prieto et al. [42]. The pure aluminium and secondary aluminium foams have a relative density of 0.46 , porosity of $82 \%$, and pore diameter of $3 \mathrm{~mm}$.

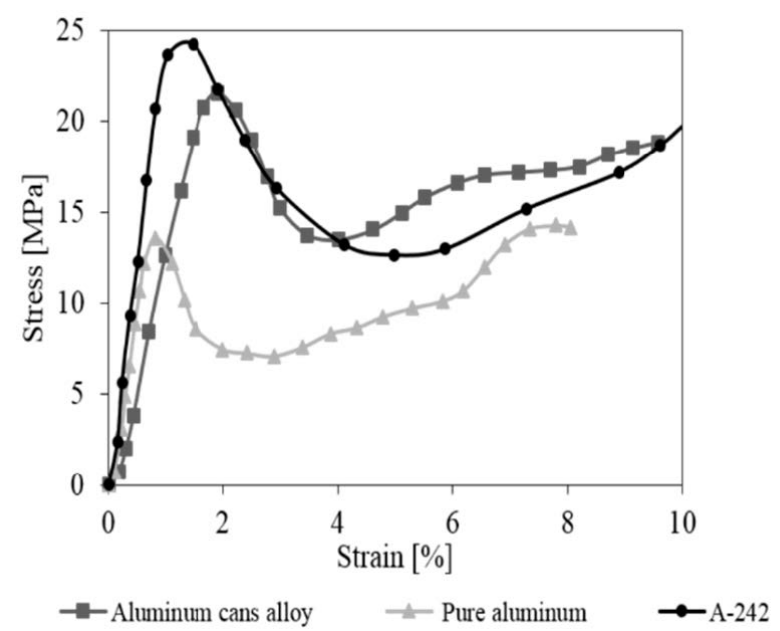

Figure 7. Stress-strain curves of a pure aluminium foam, an aluminium foam of an alloy prepared from beverage cans, and foams prepared with the A-242 aluminium alloy prepared in this work. 
As can be observed in this figure, the foam of A-242 aluminium alloy prepared with 0.75 wt. $\% \mathrm{TiH}_{2}$ at $948 \mathrm{~K}$ presents the highest mechanical strength $(24.13 \mathrm{MPa})$ and short plateau zone, as compared to foams prepared with pure aluminium (13 MPa) and secondary aluminium prepared from beverage cans $(21 \mathrm{MPa})$. For the preparation of A-242 aluminium alloy foams, a lesser Ca content $(0.50 \mathrm{wt} . \%)$ is required to stabilize the aluminium alloy foam, as well as a lesser content of $\mathrm{TiH}_{2}$ to get low relative density values (0.13), a porosity of $82 \%$, and a pore size of $1.5 \mathrm{~mm}$. This could be an advantage for developing this kind of foam at an industrial level. In addition, due to the high $\mathrm{Cu}$ content in the A-242 aluminium alloy, the A-242 aluminium alloy foams can be thermally treated in order to improve their mechanical properties. The addition of $\mathrm{TiH}_{2}$ during foaming seems to also affect grain refinement during solidification; the $\mathrm{TiAl}_{3}$ particles formed improve the mechanical resistance of the aluminium alloy [43].

On the other hand, Ca particles seem to greatly affect the collapsing behavior of the foam during compression testing, as $\mathrm{Ca}$ forms new intermetallic compounds with $\mathrm{Cu}$, weakening the foam wall and causing the fracture of the same before the application of the compression load [44]. Due to this fact, in this work we propose the use of a lower content of Ca to stabilize the aluminium alloy foam and avoid the formation of $\mathrm{Cu}$-rich intermetallic compounds with calcium.

\subsection{Microstructural Analysis}

Figure 8 shows micrographs obtained via SEM where the pore walls of aluminium alloy foams with different contents of $\mathrm{TiH}_{2}$ are evident. The aluminium alloy foams depicted were obtained as follows: a) 0.50 wt. $\% \mathrm{TiH}_{2}$, b) $0.75 \mathrm{wt} \% \mathrm{TiH}_{2}$, c) $1.00 \mathrm{wt} \% \% \mathrm{TiH}_{2}$ at $948 \mathrm{~K}$. The intermetallic phases were identified using EDS in the SEM. The microstructure of the aluminium alloy foam cell wall is composed of aluminium dendrites, in addition to intermetallic compounds of $\mathrm{Al}_{2} \mathrm{Cu}$ (alternating lamellae of $\alpha-\mathrm{Al}+\theta-\mathrm{Al}_{2} \mathrm{Cu}$ ). Intermetallic compounds of the $\mathrm{Al}_{9} \mathrm{FeNi}$ and $\mathrm{Al}_{3} \mathrm{Fe}$ in their acicular forms and polymorphs of the $\mathrm{Al}_{2} \mathrm{CuMg}$ intermetallic compound are evident. The presence of Fe- and Mg-rich intermetallics comes from the raw material (beverage cans), in contrast to those rich in $\mathrm{Ni}$ and $\mathrm{Cu}$, which come from the alloying elements added to adjust the chemical composition of the alloy. The presence of Ti-rich particles is a product of the decomposition reaction of the foaming agent $\left(\mathrm{TiH}_{2}\right)$ during the process of frothing, where $\mathrm{Al}_{3} \mathrm{Ti}$ is formed by the reaction between aluminium and titanium. The cooling rate and the chemical composition of the aluminium foam are the main variables that determine the morphology, size and distribution of the different intermetallic compounds.

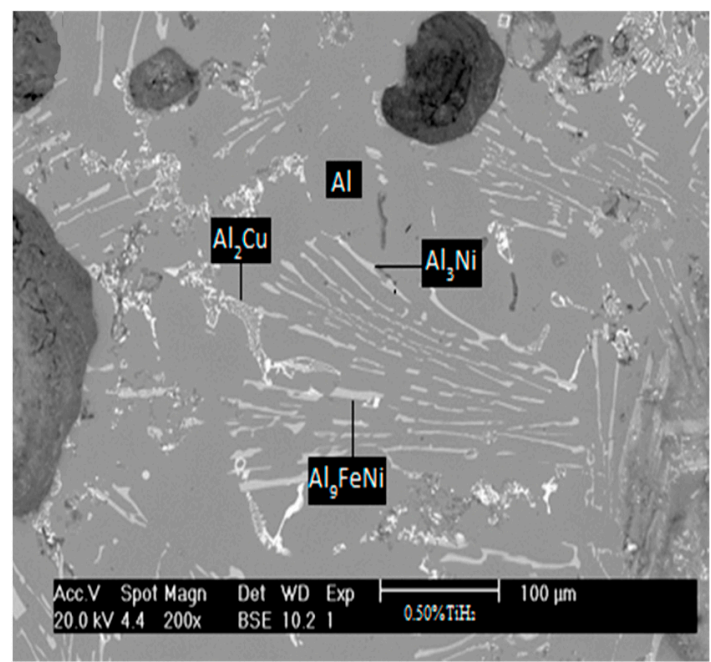

(a)

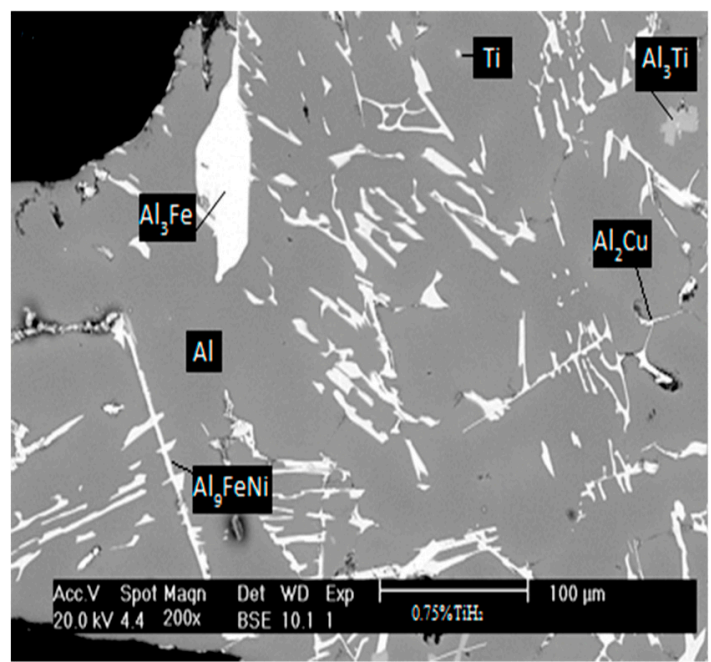

(b)

Figure 8. Cont. 


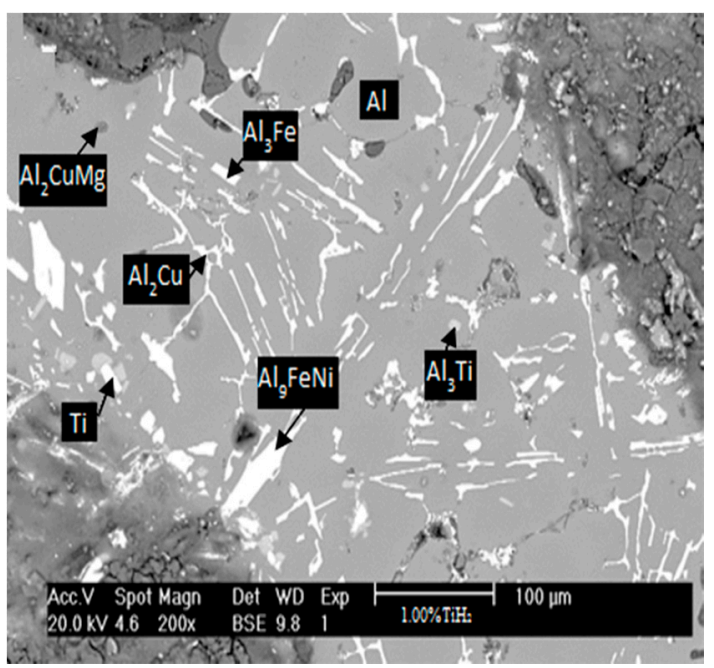

(c)

Figure 8. Micrographs of A-242 aluminium alloy foams: (a) 0.50 wt.\% $\mathrm{TiH}_{2}$; (b) 0.75 wt.\% $\mathrm{TiH}_{2}$; and (c) $1.00 \mathrm{wt} . \% \mathrm{TiH}_{2}$ at $948 \mathrm{~K}$.

Figure 9 shows a micrograph obtained through SEM of a Ti-rich particle, surrounded by particles of the $\mathrm{Al}_{3} \mathrm{Ti}$ intermetallic compound, in an A-242 aluminium alloy foam prepared with $1.00 \mathrm{wt} . \%$ $\mathrm{TiH}_{2}$ at $948 \mathrm{~K}$. The compound $\mathrm{Al}_{3} \mathrm{Ti}$ appears when the processing temperature is low, and the $\mathrm{Al}_{3} \mathrm{Ti}$ intermetallic gives the alloy greater mechanical strength [45]. The appearance of this intermetallic compound based on the equilibrium diagram is due to the preparation conditions used during the process (reaction time and foaming temperature). Figure 10 shows EDS patterns of the matrix, Ti-rich particle and $\mathrm{Al}_{3} \mathrm{Ti}$ intermetallic.

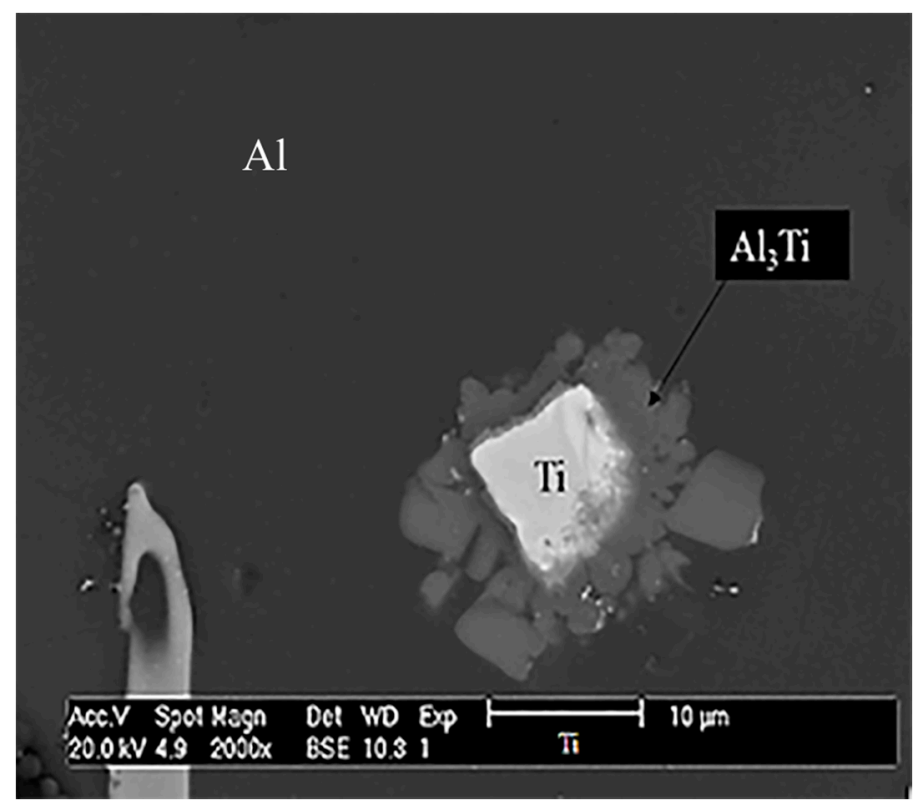

Figure 9. SEM micrograph of a Ti-rich particle, presumably the $\mathrm{Al}_{3} \mathrm{Ti}$ intermetallic compound. 


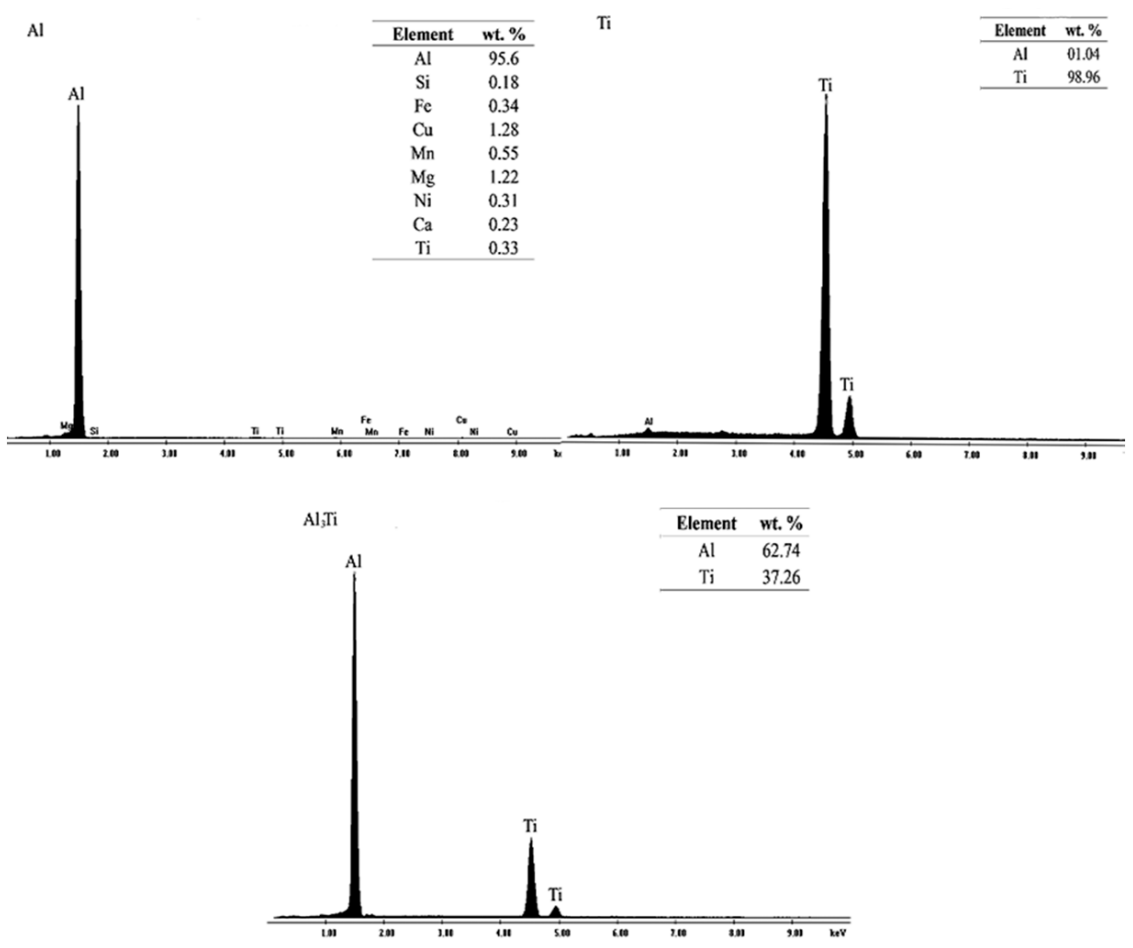

Figure 10. Energy dispersion spectroscopy (EDS) patterns for the Ti-rich particle.

\section{Conclusions}

From the results obtained in this work, it is important to emphasize the possibility of using secondary aluminium for the preparation of aluminium alloy foams with characteristics similar to those obtained by the use of commercial-purity elements.

Aluminium alloy foams were prepared with closed porosity in the order of $88.22 \%$ and with a relative density of 0.12 . The pore size was $1.29 \mathrm{~mm}$, and the wall thickness was $114.67 \mu \mathrm{m}$.

Various intermetallic compounds were identified scattered on the pore walls, such as $\mathrm{Al}_{2} \mathrm{Cu}$, $\mathrm{Al}_{9} \mathrm{FeNi}, \mathrm{Al}_{3} \mathrm{Fe}, \mathrm{Al}_{2} \mathrm{CuMg}$, Ti, and $\mathrm{Al}_{3} \mathrm{Ti}$. The aluminium alloy foams manufactured with $1.00 \mathrm{wt} . \%$ $\mathrm{TiH}_{2}$ showed higher concentrations of intermetallics.

With low $\mathrm{TiH}_{2}$ contents $(0.50 \mathrm{wt} . \%$ and $0.75 \mathrm{wt} . \%)$, the samples presented high mechanical strength values; when analyzing the microstructure of this group of samples, it was observed that they present lower contents of intermetallic compounds distributed in the pore wall and the thickness of thinner wall.

The temperature of $948 \mathrm{~K}$ turned out to be the best temperature for foaming because the resulting aluminium alloy foams presented the highest values of compressive strength.

The aluminium alloy foams prepared from the A-242 aluminium alloy presented higher values of mechanical strength and lower relative density values when compared to foams prepared using commercial-purity elements.

Author Contributions: Investigation: N.M.T.R.; Supervision: J.T.T. and A.F.V.

Funding: This research was financed by the research stimulus program of CONACYT Mexico.

Acknowledgments: The authors thank the Consejo Nacional de Ciencia y Tecnología (CONACYT) and the Centro de Investigación y de Estudios Avanzados del Instituto Politécnico Nacional (CINVESTAV) Unidad Saltillo for their support in making the realization of this project possible.

Conflicts of Interest: The authors declare no conflicts of interest. 


\section{References}

1. Castillo, E.; Hector, E. Caracterización y Recuperación (Reciclado) de Chatarra de Aluminio (Latas). Bachelor's Thesis, Universidad Nacional Autónoma de México, Mexico City, Mexico, 1995.

2. Stotz, P.; Niero, M.; Bey, N.; Paraskevas, D. Environmental screening of novel technologies to increase material circularity: A case study on aluminium cans. Resour. Conserv. Recycl. 2017, 127, 96-106. [CrossRef]

3. Bauxite Index. Available online: https://thebauxiteindex.com/en/cbix/industry-101/alumina-101/ production-trade/outlook\#alumina_101 (accessed on 10 July 2018).

4. European Aluminium. Available online: https://www.european-aluminium.eu/about-aluminium/ aluminium-in-use/ (accessed on 16 July 2018).

5. Paraskevas, D.; Kellens, K.; Dewulf, W.; Duflou, J.R. Environmetal modelling of aluminium recycling: A Life Cycle Assessment tool for sustainable metal management. J. Clean. Prod. 2015, 105, 357-370. [CrossRef]

6. United Nations Environment Programme. Available online: https://wedocs.unep.org/bitstream/handle/ 20.500.11822/8702/Recycling\%20rates\%20of\%20metals:\%20A20status\%20report2011Recycling_Rates.pdf? amp\%3BisAllowed=\&sequence=3 (accessed on 24 April 2018).

7. United Nations Environment Programme. Available online: https://www.unenvironment.org/resources/ report/metal-recycling-opportunities-limits-infrastructure (accessed on 24 April 2018).

8. Modaresi, R.; Müller, D.B. The role of automobiles for the future of aluminum recycling. Environ. Sci. Technol. 2012, 46, 8587-8594. [CrossRef]

9. Paraskevas, D.; Kellens, K.; Van de Voorde, A.; Dewulf, W.; Duflou, J.R. Environmetal impact analysis of primary aluminium production at country level. Procedia CIRP 2016, 40, 209-213. [CrossRef]

10. Comercio Exterior Bancomext. Available online: www.revistacomercioexterior.com/articulo.php?id=120\&t= la-industria-del-aluminio-en-mexico (accessed on 16 July 2018).

11. American Society for Metals. ASM Metals Handbook, Properties and Selection: Nonferrous Alloys and Special-Purpose Materials; ASM International: Geauga County, OH, USA, 1990; Volume 2, pp. 583-590.

12. American Society for Metals. ASM Metals Handbook, Casting; ASM International: Geauga County, OH, USA, 2008; pp. 44-49.

13. Fuki, T.; Nonaka, Y.; Suzuki, S. Fabrication of Al-Cu-Mg Alloy Foams Using Mg as Thickener Through Melt Route and Reinforcement of Cell Walls by Heat Treatment. Procedia Mater. Sci. 2014, 4, 33-37. [CrossRef]

14. Gibson, L.J. Mechanical Behavior of Metallic Foams. Ann. Rev. Mater. Sci. 2002, 30, 191-227. [CrossRef]

15. Banhart, J.; Baumeister, J. Deformation characteristics of metal foams. Mater. Sci. 1998, 33, 1431-1440. [CrossRef]

16. García-Moreno, F. Commercial Application of Metal Foams: Their Properties and Production. J. Mater. Sci. 2016, 9, 85. [CrossRef] [PubMed]

17. Banhart, J. Manufacture, characterization and application of cellular metals and metal foam. Prog. Mater. Sci. 2001, 46, 559-632. [CrossRef]

18. Davies, G.J.; Zhen, S. Metallic foams: Their production, properties and applications. J. Mater. Sci. 1983, 18, 1899-1911. [CrossRef]

19. Nakajima, H. Fabrication, properties and application of porous metals with directional pores. Prog. Mater. Sci. 2007, 52, 1091-1173. [CrossRef]

20. Kranzlin, N.; Niederberger, M. Controlled fabrication of porous metals from the nanometer to the macroscopic scale. Mater. Horiz. 2015, 2, 359-377. [CrossRef]

21. Qin, J.; Chen, Q.; Yang, C.; Huang, Y. Research process on property andapplication of metal porous materials. J. Alloys Compd. 2016, 654, 39-44. [CrossRef]

22. Lefebvre, L.P.; Banhart, J.; Dunand, D.C. Porous metals and metallic foams: Current status and recent developments. Adv. Eng. Mater. 2008, 10, 775-787. [CrossRef]

23. Ashby, M.F.; Evans, A.G.; Fleck, N.A.; Gibson, L.J.; Hutchinson, J.W.; Wadley, H.N.G. Metal Foams: A Design Guide; Butterworth-Heinemann: Boston, MA, USA, 2000.

24. Baumeister, J.; Weise, J. Metallic foams. In Ullmann's Encyclopedia of Industrial Chemistry; Wiley-VCH Verlag GmbH \& Co. KGaA: Weinheim, Germany, 2000.

25. Weaire, D.; Cox, S.J.; Banhart, J. Methods and models of metallic foam fabrication. In Proceedings of the 8th Annual International Conference on Composites Engineering, Canary Islands, Spain, 5-11 August 2001; pp. 977-978. 
26. Gibson, L.; Ashby, M. Cellular Solids: Structure and Properties; Cambridge University Press: Cambridge, UK, 1997.

27. Akiyama, S.; Ueno, H.; Imagawa, K.; Kitahara, A.; Nagata, S.; Morimoto, K.; Nishikawa, T.; Itoh, M. Foamed Metal and Method of Producing Same. U.S. Patent 4,713,277, 15 December 1987.

28. Jin, I.; Kenny, L.D.; Sang, H. Method of Producing Lightweight Foamed Metal. U.S. Patent 4,973,358, 27 November 1990.

29. Allen, B.C.; Mote, M.W.; Sabroff, A.M. Method of Making Foamed Metal. U.S. Patent 3,087,807, 30 April 1963.

30. Asavavisithchai, S.; Kennedy, A.R. Effect of powder oxide content on the expansion and stability of PM-route Al foams. J. Colloid Interface Sci. 2006, 297, 715-723. [CrossRef]

31. Weaire, D.; Hutzler, S. The Physics of Foams; Oxford University Press: Oxford, UK, 1999.

32. Hall, I.W.; Guden, M.; Yu, C.-J. Crushing of aluminum closed cell foams: Density and strain rate effects. Scr. Mater. 2000, 43, 515-521. [CrossRef]

33. Olurin, O.B.; Fleck, N.A.; Ashby, M.F. Deformation and fracture of aluminium foams. Mater. Sci. Eng. A 2000, 291, 136-146. [CrossRef]

34. Kennedy, A.R. Aspects of the reproducibility of mechanical properties in Al based foams. J. Mater. Sci. 2004, 39, 3085-3088. [CrossRef]

35. Ramamurty, U.; Paul, A. Variability in mechanical properties of a metal foam. Acta Mater. 2004, 52, 869-876. [CrossRef]

36. Beals, J.T.; Thomson, M.S. Density gradient effects on aluminium foam compression behaviour. J. Mater. Sci. 1997, 32, 3595-3600. [CrossRef]

37. Antônio, A.; Oliveira, J.R.; Marques, R. Thixoforging of Al-3.8\% Si alloy recycled from aluminum cans. Mater. Sci. Eng. A 2014, A607, 219-225. [CrossRef]

38. Soltani, R.; Sarajan, Z.; Soltani, M. Foaming of pure aluminium by $\mathrm{TiH}_{2}$. Mater. Res. Innov. 2014, 18, 401-406. [CrossRef]

39. Geramipour, T.; Oveisi, H. Effects of foaming parameters on microstructure and compressive properties of aluminum foams produced by powder metallurgy method. Trans. Nonferrous Met. Soc. China 2014, 27, 1569-1579. [CrossRef]

40. Duarte, I.; Banhart, J. A study of aluminium foam formation kinetics and microstructure. Acta Mater. 2000, 48, 2349-2362. [CrossRef]

41. Baumeister, J.; Banhart, J.; Weber, M. Aluminium Foam for Transport Industry. Mater. Des. 1997, 18, $217-220$. [CrossRef]

42. Prieto, V.; Torres, J.; Flores, A. Recycling of aluminum beverage cans for metallic foams manufacturing. J. Porous Mat. 2017, 24, 707-712. [CrossRef]

43. Li, P.; Kandalova, E.G.; Nikitin, V.I. Grain refining performance of Al-Ti master alloys with different microstructures. Mater. Lett. 2005, 59, 723-727. [CrossRef]

44. Huang, L.; Wang, H.; Yang, D.H.; Ye, F.; Wang, S.Q.; Lu, Z.P. Effects of calcium on mechanical properties of celular Al-Cu foams. Mater. Sci. Eng. A 2014, A618, 471-478. [CrossRef]

45. Mishin, Y.; Herzing, C. Diffusion in the Ti-Al system. Acta Mater. 2000, 48, 589-623. [CrossRef]

(C) 2019 by the authors. Licensee MDPI, Basel, Switzerland. This article is an open access article distributed under the terms and conditions of the Creative Commons Attribution (CC BY) license (http://creativecommons.org/licenses/by/4.0/). 